\title{
ANALYSIS OF DEFERASIROX AND DEFERIPRON USE IN CHILDREN WITH PEDIATRIC $\beta$-THALASSEMIA MAJOR
}

\author{
Evy Sari Sutrisnaningsih ${ }^{1}$, Suharjono $^{1}$, Bambang Sudarmanto ${ }^{2}$ \\ ${ }^{1}$ Department of Clinical Pharmacy, Faculty of Pharmacy, Universitas Airlangga, Surabaya \\ ${ }^{2}$ Department of Pediatrics, Dr Karjadi Hospital, Semarang
}

\begin{abstract}
ABSTRAK
$\beta$-Thalassemia mayor merupakan penyakit genetik akibat penurunan dan produksi yang tidak sempurna dari hemoglobin. Manifestasi klinik adalah terjadinya anemia, diatasi dengan pemberian transfusi darah rutin. Transfusi darah menyebabkan peningkatan besi dalam tubuh yang dapat mengakibatkan komplikasi organ. Pemberian obat kelasi besi diharapkan mampu mengurangi komplikasi akibat peningkatan jumlah besi dalam tubuh melalui pengukuran serum feritin. Penelitian bertujuan menganalisis penggunaan deferasirox dan deferipron pada pasien anak $\beta$-thalassemia mayor di RSUP Dr. Kariadi Semarang dari 1 Januari 2012 hingga 31 Desember 2013 serta kebutuhan transfusi darah. Pasien yang memenuhi kriteria inklusi, yaitu pasien anak $\beta$-thalassemia mayor, secara retrospektif dilakukan pengamatan terhadap data rekam medis antara lain data dasar dan data laboratorium. Setelah itu dilakukan analisis deskriptif untuk mengetahui penggunaan dua jenis obat kelasi besi tersebut. Pada penelitian ini 9 pasien masuk dalam kriteria inklusi. Sebanyak 5 orang menggunakan deferasirox dan 4 orang menggunakan deferipron pada awal penelitian. Terdapat 3 orang yang berubah deferipron menjadi deferasirox. Nilai serum feritin pada awal penelitian adalah $>1200 \mu \mathrm{g} / \mathrm{L}$, dan pada akhir penelitian serum feritin masih $>1200 \mu \mathrm{g} / \mathrm{L}$. Dosis rerata deferasirox penelitian

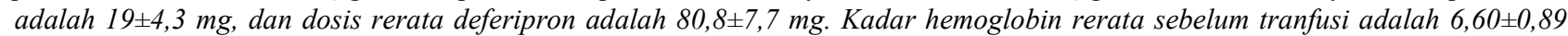
$\mathrm{mg} / \mathrm{dL}$. Jumlah rerata transfusi darah yang diberikan adalah 336,52 $\pm 73,85 \mathrm{ml}$. Jenis transfusi darah yang digunakan adalah Washed erythrocyte. Splenomegali terjadi pada 2 pasien. Tidak ada perubahan fungsi ginjal dan hepar yang berarti. Hasil penelitian disimpulkan target penurunan serum feritin hingga $<1000 \mu \mathrm{g} / \mathrm{L}$ belum tercapai. Dosis deferasirox masih dapat ditingkatkan untuk mencapai target serum feritin yang diharapkan. (FMI 2016;52:42-46)
\end{abstract}

Kata kunci: $\beta$-Thalassemia Mayor, Anak, Deferasirox, Deferipron

\begin{abstract}
$\beta$-thalassemia major is a genetic disease and a decline in production due to imperfect of hemoglobin. Clinical manifestations are anemia, treated with regular blood transfusions. Blood transfusions lead to an increase in iron in the body that can lead to organ complications. Iron chelation drug delivery is expected to reduce complications due to an increase in the amount of iron in the body by measuring serum ferritin. The study aims to analyze the use of deferasirox and deferipron in patients with $\beta$-thalassemia major children at Dr. Kariadi Hospital of January 1, 2012 until December 31, 2013 as well as the need for blood transfusions. Patients who met the inclusion criteria, ie patients with $\beta$-thalassemia major children, retrospectively conducted observations of medical records include basic data and laboratory data. After descriptive analysis was performed to determine the use of two types of iron chelating drugs. In this study, 9 patients included in the inclusion criteria. A total of 5 people using deferasirox and 4 using deferipron at baseline. There are 3 people who turned deferipron be deferasirox. Serum ferritin values at study entry was $>1200$ $\mathrm{mcg} / \mathrm{L}$, and at the end of the study serum ferritin is $>1200 \mathrm{mcg} / \mathrm{L}$. The mean dose of deferasirox study was $19 \pm 4.3 \mathrm{mg}$, and the dose deferipron mean was $80.8 \pm 7.7 \mathrm{mg}$. Mean hemoglobin levels before transfusion was $6.60 \pm 0.89 \mathrm{mg} / \mathrm{dL}$. The average number of blood transfusions given was $336.52 \pm 73.85 \mathrm{ml}$. Type of blood transfusion is used Washed erythrocyte. Splenomegaly occurred in 2 patients. There is no change in renal function, and hepatic meaning. The final conclusion until the reduction target serum ferritin $<1000 \mathrm{mg} / \mathrm{L}$ has not been reached. Deferasirox dose can be increased to achieve the expected serum ferritin. (FMI 2016;52:42-46)
\end{abstract}

Keywords: $\beta$-thalassemia mayor, childern, deferasirox, deferipron

Correspondence: Evy Sari Sutrisnaningsih, Tampomas 3 No 45 Semarang. Phone: 085731744443. Email: Evy_pharm@yahoo.com

\section{INTRODUCTION}

In Indonesia the number of thalassemia patients by the year 2009 rose to $8.3 \%$ of 3,653 patients were registered in 2006 (Ruswandi 2009). $\beta$-thalassemia major is a genetic disease and a decline in production due to imperfect of hemogblobin, a molecule that is in the red blood cells that carries oxygen throughout the body. Patients with thalassemia may suffer from mild anemia 
with or without effects, whereas other patients in need of serious therapy treatment. Routine blood cell transfusions eliminates the complications of anemia and cessation eritropoeisis, and extend the holding time thalassemia major patients (Olivieri \& Weatherall 2006). Routine blood transfusions can cause a buildup of iron in the blood (Turgeon 2011). Excessive iron buildup can cause complications in other organs such as endocrine, liver, heart and death (Agarwal 2009).

Iron chelating drug used to bind the iron that is not bound to transferrin in the blood and eliminate through urine or feces. Deferoksamin given by parenteral administration, while deferipron and deferasirox administered orally (Olivier 1997). Combination use DFP for five days and continued DFO two days gave better results than the use DFP monotherapy for seven days in terms of the measurement of serum ferritin level, Liver Iron Concentration (LIC) (Aydinok et al 2007). To defera-sirox clinical trials in adult patients with a mean age range of 24.6 years showed a decrease in serum ferritin of $3175 \mathrm{ug} / \mathrm{L}$ to $2451 \mu \mathrm{g} / \mathrm{L}$. Priyanti-ningsih's research using deferasirox showed that for six months did not decrease significantly serum ferritin. The patient's baseline serum ferritin above $1000 \mathrm{mg} / \mathrm{L}$, after six months the mean serum ferritin pediatric patients is $1182.3 \mu \mathrm{g} / \mathrm{L}$ (Priyatiningsih 2010). Currently, iron chelating drug studies in pediatric patients are still rare, especially in Indonesia. Based on this, this study aims to evaluate the effectiveness and safety of deferasirox in patients with $\beta$ thalassemia major children who received transfusions.

\section{MATERIAL AND METHODS}

The inclusion criteria of this study include pediatric patients hospitalized and outpatients with a diagnosis of $\beta$-thalassemia major for January 1, 2011 until July 31, 2014 patients received blood transfusions, patients have received the drug chelation of iron for two years, The presence of the examination of serum ferritin for administration iron chelating drug. Exclusion criteria such as patients who discontinue iron chelation therapy. Clinical data from these patients were obtained retrospectively by medical record review, and this study was approved by the Institutional Review Aboard of Medical school Diponegoro University.

Data collected for each patient consisted of the following: complete blood count (CBC); ferritin, serum creatinine, aspartate aminotransferase (AST), and alanine aminotransferase (ALT) levels; concomitantly used drugs; and complications occurring between the start and end of deferasirox and deferiprone use. Continuous variables are summarized by descriptive statistics, including the mean and range. Categorical variables are presented as the number and percentage in each category.

\section{RESULTS}

\section{Patient characteristics}

Nine patients ( 4 boys and 5 girls; mean : 10 years) who were treated with deferasirox and deferiprone from January 1, 2012 to Desember 31, 2013 were enrolled in this study. The general clinical characteristics of these 9 patients are provided in Table 1.

Table 1. Demographic data for the 9 patients in the analysis of deferasriorx and deferiprone use

\begin{tabular}{cc}
\hline Variables & Patients $(\mathrm{n}=9)$ \\
\hline Age $($ years $)$ & 3 \\
$0-5$ & 5 \\
$>5-11$ & 1 \\
$>11-16$ & \\
Gender & 4 \\
Male & 5 \\
Female & \\
Nutritional status & 8 \\
Good nutrition & 1 \\
Better nutrition & \\
\hline
\end{tabular}

A total of 5 people using deferasirox and 4 using deferipron at baseline. There are 3 people who turned deferipron be deferasirox. The distribution of regimen change is shown in Fig. 1.

\section{Change in serum ferritin}

Among the 9 patients who met the requirements for the analysis, serum ferritin at baseline was $>1200 \mathrm{mcg} / \mathrm{L}$, and after 24 months of chelator drug use, serum ferritin was still $>1200 \mathrm{mcg} / \mathrm{L}$ is shown in Fig. 2.

\section{Deferasirox and deferiprone dose}

The mean dose pediatric patients with $\beta$-thalassemia major in this study were $(19.0 \pm 4.3 \mathrm{mg})$ for deferasirox and $(80.8 \pm 7.7) \mathrm{mg}$ for deferipron. In this study, there were $71 \%$ dosing and $29 \%$ dose below a dose of literature that is $20-30 \mathrm{mg} / \mathrm{kg}$ /day for deferasirox and $75-100 \mathrm{mg} / \mathrm{kg} /$ day for deferipron. 


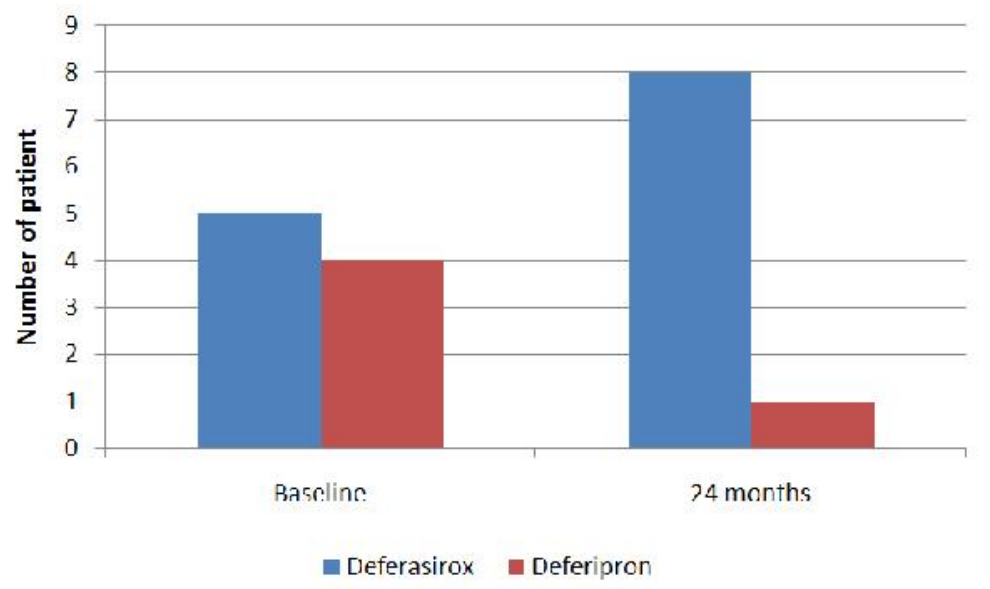

Fig. 1. Distribution of regimen change for 9 patients at baseline and after 24 months study

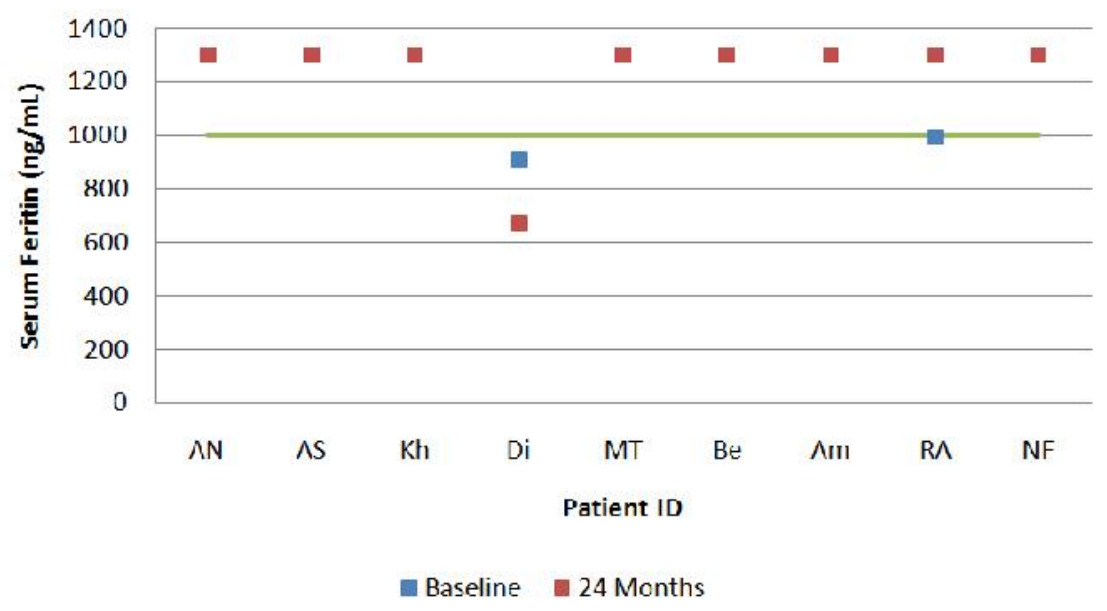

Fig. 2. Serum feritin levels for the 9 patients included in the analysis of iron chelation drug

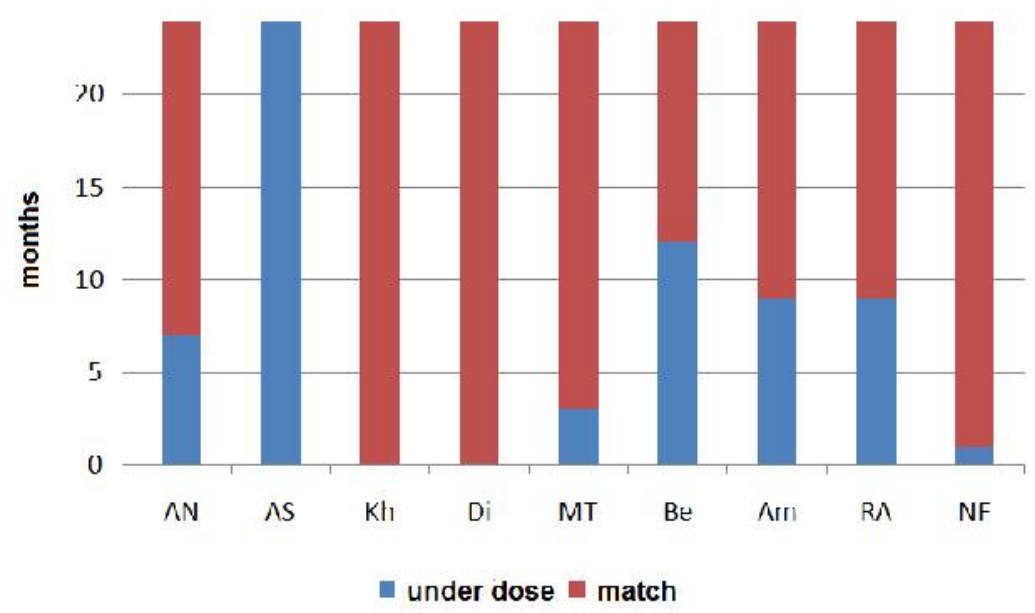

Fig. 3. Distribution of 9 patients for months underdose use 


\section{Blood transfusion}

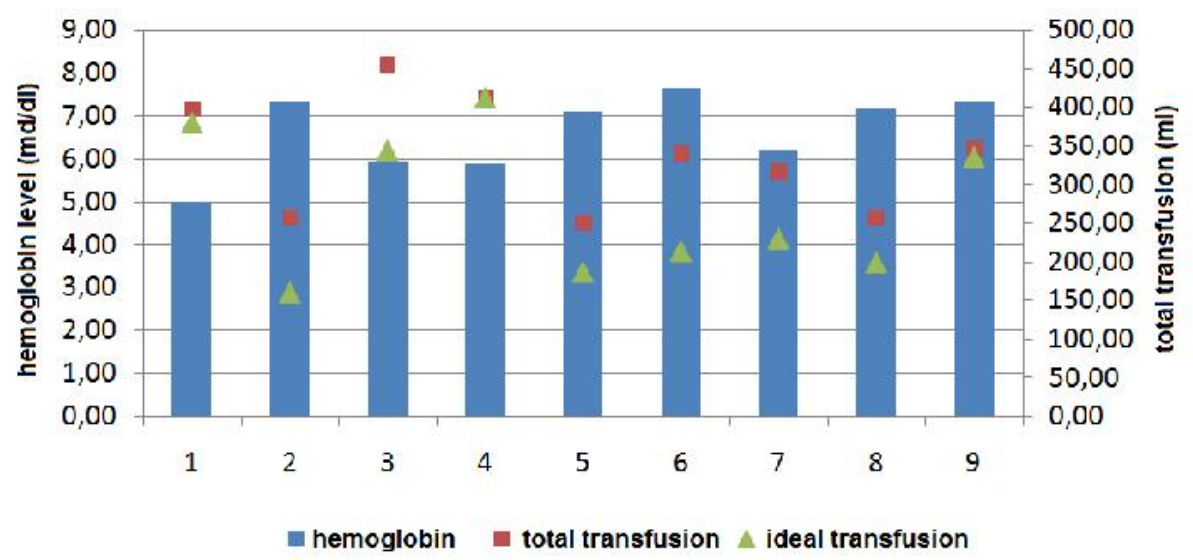

Fig. 4. Need for blood transfusion in accordance with initial hemoglobin

Giving blood transfusion in this study the most widely prescribed for once a month by $58 \%$, giving two months as much as $23 \%$, the provision for 3 months and less than once a month each as much as $6 \%$, and $8 \%$ is given for the above three months. Given blood type is Washed Erytrocyte, namely red blood antibody that has been removed.

\section{DISCUSSION}

Thalassemia disease can be detected at an early age. This is caused by a disease thalassemia is a descendant of both parents. Generally, signs of the disease will appear at a younger age, usually after birth or a few months after birth (Ganie 2005). In the study in Korea, the number of samples is 17 patient study, derived from seven hospitals that receive iron chelation drug treatment for 3 years. The mean age of patients was 4 years old and the median age was 10.6 years. Administration of iron chelating drugs can be seen its effectiveness one through serum ferritin.

Target serum ferritin in patients with $\beta$-thalassemia major is $<1000 \mathrm{ng} / \mathrm{mL}$. In the survey results revealed that the serum ferritin is not appropriate treatment targets for two years administration of iron chelating drugs. This is indicated by serum ferritin values at study entry was $>1200 \mathrm{ng} / \mathrm{mL}$ and at the end of the study> $1200 \mathrm{ng} / \mathrm{mL}$ in 8 patients. There is one patient who had a serum values below $1000 \mathrm{ng} / \mathrm{mL}$ which is the average of $801 \mathrm{ng} / \mathrm{mL}$. Measurement of serum ferritin in this study has limited sensitivity of the tool. Checker tool can not detect the value of serum ferritin $>1200 \mathrm{ng} / \mathrm{mL}$. Another study by Won, there is a decrease in serum ferritin in pediatric patients who use deferipron for 3 years from the baseline $4677.8 \pm 1130.9 \mathrm{ng} / \mathrm{mL}$ to
$3363.9 \pm 1149.7 \mathrm{ng} / \mathrm{mL}$. Won the study showed a decline, but the decline is still not in accordance with the target serum ferritin (Won 2010).

Of the value of serum ferritin in patients receiving iron chelation drug known to change in serum ferritin values $>1200 \mathrm{ng} / \mathrm{mL}$. This shows the possibility of granting deferipron not show the expected results so that clinicians replace with deferasirox. Changes in iron chelation drug is still not showing the expected results. The mean serum ferritin patient is still> $1200 \mathrm{ng} / \mathrm{mL}$ with deferasirox administration at the end of the study. Deferipron doses given are in accordance with the normal dosage is $75-100 \mathrm{mg} / \mathrm{kg} /$ day. Deferasirox dose is $20-40 \mathrm{mg} / \mathrm{kg} / \mathrm{day}$. The mean dose pediatric patients with $\beta$-thalassemia major in this study were $(19.0 \pm 4.3 \mathrm{mg})$ for deferasirox and $(80.8 \pm 7.7) \mathrm{mg}$ for deferipron.

Washed erythrocyte indicated in patients with allergies who need repeated transfusions, patients who have antibodies to plasma proteins, patients with nocturnal hemoglobinuria paroxysmal. The mean number of blood transfusions as much as $336.52 \pm 73.85 \mathrm{ml}$. Giving such a blood transfusion $\mathrm{Hb}$ values adjusted to the patient before transfusion, the patient's weight, and the target $\mathrm{Hb}$. Target $\mathrm{Hb}$ in patients with $\beta$-thalassemia major is $10 \mathrm{mg} / \mathrm{dL}$. Number of transfusions is not given directly to the patient's children, but it is divided and given to the smaller volume first, followed with transfusion four hours later. It is intended that the heart load is not too large (Agarwal 2009). Results of previous studies stated thalassemia patients begin transfusion mean age of 3.78 years, and the frequency of transfusion mostly 1 month 1 time $(87.5 \%)$. One of its management is to provide the required amount of blood by the blood provider for a blood transfusion in order that the needs of patients with 
thalassemia can be fulfilled each time transfusing so that thalassemia patients can survive well.

After administration of deferasirox over three years in patients with $\beta$-thalassemia major children known to an increase in urea, increased creatinine, SGOT and SGPT not occur significantly. The normal value of urea is 15 $39 \mathrm{mg} / \mathrm{dL}$, creatinine normal value is 0.60 to 1.30 $\mathrm{mg} / \mathrm{dL}$, AST normal value is 15-37 U/L, ALT normal value is $30-65 \mathrm{U} / \mathrm{L}$. There is one patient experienced an increase in AST and ALT more than 3 times. Deferasirox side effect is vomiting mild/moderate $(8.3 \%)$, nausea (7.1\%) and rash (7.5\%) (Taher et al 2007). Complications of the disease $\beta$-thalassemia major, among others disturbance in endocrine, liver, and heart. A total of two patients had splenomegaly, or enlargement of the spleen. One of them has done splenectomy.

\section{CONCLUSION}

The reduction target serum ferritin $<1000 \mathrm{mg} / \mathrm{L}$ has not been reached. Deferasirox dose can be increased to achieve the expected serum ferritin.

\section{REFERENCES}

Agarwal MB (2009). Advances in management thalassemia. Indian Journal of Pediatrics 76, 177-184
Aydinok Y, Ulger Z, Nart D, Terzi A, Cetiner N, Ellis G, Zimmermann A, Manz C (2007). A randomized controlled 1-year study of daily deferiprone plus twice weekly desferrioxamine compared with daily deferiprone monotherapy in patients with thalassemia major. Haematologica 92, 1599-1606

Ganie RA (2005). Thalassemia: permasalahan dan penanganannya. Pidato Pengukuhan Jabatan Guru Besar Tetap dalam Bidang Ilmu Patologi pada Fakultas Kedokteran, Universitas Sumatera Utara, Presented in Medan November 16, 2005

Olivieri NF and Weatherall DJ (2006). Thalassemias. In: Arceci RJ, Hann IM, Smith OP, Hoffbrand AV (eds). Pediatric Hematology 3rd Ed, Massachusetts, Blackwell Publishing, p 281-305

Priyatinigsih DR (2010). Pengaruh deferasirox terhadap kadar T4 dan TSH pada penderita $\beta$-Thalassemia Mayor dengan feritin yang tinggi. Thesis. Universitas Diponegoro, Semarang

Ruswandi (2009). Jumlah penderita thalassemia naik 8,3\%. Available from http://kesehatan.kompas.com/ $\mathrm{read} / 2009 / 03 / 05 / 21122544 / J u m l a h . P e n d e r i t a . T h a l a s s e$ mia.Naik.8.3.Persen. Accessed March 5, 2009

Turgeon ML (2011). Clinical Hematology Theory and Procedures 5th ed, Philadephia, Lippincott Williams \& Wilkins, p 220-223

Won SC, Han DK, Seo JJ, Chung NG, Park SK, Park KB, Kook H, Lyu CJ (2010). Efficacy and safety of deferiprone (Ferriprox), an oral iron-chelating agent, in pediatric patients. Korean J Hematol 45, 58-61 